\section{Safety of besifloxacin ophthalmic suspension $0.6 \%$ in refractive surgery: a retrospective chart review of post-LASIK patients [Corrigendum]}

Nielsen SA, McDonald MB, Majmudar PA. Safety of besifloxacin ophthalmic suspension $0.6 \%$ in refractive surgery: a retrospective chart review of post-LASIK patients. Clinical Ophthalmology. 2013;7:149-156.

The paper titled "Safety of besifloxacin ophthalmic suspension $0.6 \%$ in refractive surgery: a retrospective chart review of post-LASIK patients," contains an inaccurate description of the intraoperative use of medications.

In the Results section it is reported that $31.8 \%(170 / 534)$ of besifloxacin cases and 97.0\% (259/267) of moxifloxacin cases had drops applied directly to the flap interface. We have determined that ambiguity in the design of the electronic case report form resulted in all day-of-surgery drops provided to patients in the LASER suite being reported in the flap interface field. The authors have since clarified with each surgeon who reported intraoperative drug use that the drops were delivered either prior to the flap creation, or following replacement of the flap.

The sentence at the top of page 152 stating: "Of note, $31.8 \%$ (170/534) of besifloxacin cases and 97.0\% (259/267) of moxifloxacin cases had drops applied directly to the flap interface" should say: "Of note, $31.8 \%$ (170/534) of besifloxacin cases and $97.0 \%$ (259/267) of moxifloxacin cases had intraoperative drops applied."
Clinical Ophthalmology

\section{Publish your work in this journal}

Clinical Ophthalmology is an international, peer-reviewed journal covering all subspecialties within ophthalmology. Key topics include: Optometry; Visual science; Pharmacology and drug therapy in eye diseases; Basic Sciences; Primary and Secondary eye care; Patient Safety and Quality of Care Improvements. This journal is indexed on

\section{Dovepress}

PubMed Central and CAS, and is the official journal of The Society of Clinical Ophthalmology (SCO). The manuscript management system is completely online and includes a very quick and fair peer-review system, which is all easy to use. Visit http://www.dovepress.com/ testimonials.php to read real quotes from published authors. submit your manuscript | www.dovepress.com

Dovepress

http://dx.doi.org/10.2147/OPTH.S4537 